\title{
A new species of Bocoa (Leguminosae-Swartzieae) from the Upper Essequibo region, Guyana
}

\author{
G.A. Aymard C. ${ }^{1}$, H.E. Ireland ${ }^{2}$
}

Key words

Bocoa

Guayana Shield

Guyana

Leguminosae-Swartzieae

taxonomy

tropical South America

\begin{abstract}
A new species, Bocoa marionii, from the Upper Essequibo region, Guyana, is described and illustrated and its relationships with allied species are discussed. It is morphologically similar to $B$. prouacensis, from which it differs in its chartaceous leaflets, shorter inflorescences borne among leaves, longer pedicels, calyx that is strigose along the middle of the segments internally, and ovary densely yellow-sericeous. A key to the species of Bocoa is provided.
\end{abstract}

Published on 16 April 2010

\section{INTRODUCTION}

Bocoa Aubl. is a small genus of slender trees found in a variety of habitats, from open canopy cerrado to tropical moist forest, distributed throughout northern South America. Until recently, it contained seven species (Cowan 1974, Cowan \& Lindeman 1989), but evidence from several different sources, including morphology (Herendeen 1995), wood anatomy (Gasson 1996) and pollen (Ferguson \& Schrire 1994), suggested that the genus was non-monophyletic, comprising elements of two separate and well-supported clades (Ireland et al. 2000, Kite \& Ireland 2002, Ireland 2005). Ireland (2007) confirmed this division by a detailed morphological study and reinstated the generic name Trischidium Tul., into which five species of Bocoa were transferred: T.alterna (Benth.) H.E.Ireland, T. decipiens (R.S.Cowan) H.E.Ireland, T. limae (R.S.Cowan) H.E.Ireland, T. molle (Benth.) H.E.Ireland and $T$. racemulosum (Huber) H.E.Ireland. She retained two species in Bocoa (B. prouacensis Aubl. and $B$. viridiflora (Ducke) R.S.Cowan) and in the same work she described a third species, B. ratteri H.E.Ireland. Ireland (2007) noted several characters that distinguish Bocoa from Trischidium, some of which had been overlooked by previous authors. For example, Bocoa species have no petals, whereas there is a single petal in all species of Trischidium (except $T$. decipiens); the anthers of Bocoa are dorsifixed, attached about $0.5 \mathrm{~mm}$ from the base of the anther, and are shorter than the filaments, whereas in Trischidium they are basifixed and as long as or longer than the filaments; the fruits of Bocoa have a woody wall with either a smooth or rough surface, in contrast to Trischidium, which has a chartaceous fruit wall with reticulate venation on the surface; and Bocoa has larger, arillate seeds. Bocoa is morphologically similar to Swartzia Schreb. and herbarium specimens are often misidentified. Indeed, Bocoa and Swartzia form a monophyletic group within the Swartzioid clade (Ireland et al. 2000). Swartzia can be readily distinguished from Bocoa by its polymorphic rather than monomorphic stamens, and filaments that are usually as long as or shorter than the anthers, rather than filaments that are longer than the anthers.

\footnotetext{
1 UNELLEZ-Guanare, Programa de R.N.R., Herbario Universitario (PORT) Mesa de Cavacas, Estado Portuguesa, Venezuela 3350; corresponding author e-mail: gaymard@cantv.net.

21 Golf Cottages, Bucklesham Road, Ipswich, Suffolk, IP3 8UG, UK; e-mail: helenireland@gmail.com.
}

One species of Bocoa (B. viridiflora) looks similar to the monospecific genus Candolleodendron R.S.Cowan (C. brachystachyum (DC.) R.S.Cowan), particularly in fruit and in the vegetative state, and both taxa share a similar geographical distribution in northern Brazil and French Guiana. Torke (pers. comm.) has confirmed this affinity in a cladistic analysis using combined data from trnL and atpB-rbcL sequences, which showed $C$. brachystachyum and $B$. viridiflora to be sisters. However, C. brachystachyum has 5-7 leaflets in contrast to the $1-3$ of $B$. viridiflora, the flowers of $C$. brachystachyum are larger and more robust than those of $B$. viridiflora, with longer (c. $5 \mathrm{~mm}$ ) anthers that are basifixed, a petal, and a densely pubescent ovary. The flowers of $B$. viridiflora differ in having smaller, dorsifixed anthers (1-1.5 mm long), no petal and a glabrous ovary.

There is much variation within the genus Bocoa. For example, the leaves of $B$. viridiflora are trifoliolate (occasionally unifoliolate) with opposite to subopposite leaflets, those of $B$. ratteri are pinnate with alternate leaflets, and those of $B$. prouacensis and $B$. marionii are unifoliolate. There is variation in stamen number: $B$. viridiflora has $25-30$ stamens, $B$. ratteri $50-65$, and $B$. prouacensis and $B$. marionii $7-10$. With so much variation it is possible that the genus is not monophyletic. We propose that all species should remain in the genus Bocoa at present until more information becomes available, particularly about the poorly known species $B$. ratteri and $B$. marionii.

\section{Bocoa marionii Aymard \& H.E.Ireland, sp. nov. — Fig. 1}

Bocoae prouacensi Aubl., sed differt: foliolis chartaceis; inflorescentiis 10-15 $\mathrm{cm}$ longis, non ramifloris, pedicellis $4-8 \mathrm{~mm}$ longis, strigoso-pubescentibus, calycis segmentis intus strigosis, ovario dense luteo-sericeo pubescenti. - Typus: M. Jansen-Jacobs et al. 5676 (holo U (2 sheets); iso PORT), Guyana, Upper Essequibo region, Rewa River, Corona falls, $03^{\circ} 10^{\prime} \mathrm{N}$, $58^{\circ} 40^{\prime} \mathrm{W}, 160 \mathrm{~m}, 31$ August 1999.

Slender tree 5-10 m tall; branchlets cylindrical, glabrous, the bark grey; stipules early deciduous. Leaves: unifoliolate, petiole 10-15 mm long, glabrous, rounded, pulvinule c. $2 \mathrm{~mm}$ long, glabrous; leaflets elliptic, elliptic-ovate to broadly ovate, 9-20 by $5-13 \mathrm{~cm}$, chartaceous, glabrous above and beneath, base acute to obtuse, apex acute; secondary veins 7-13, convergent and anastomosing close to the margin, tertiary venation im- 

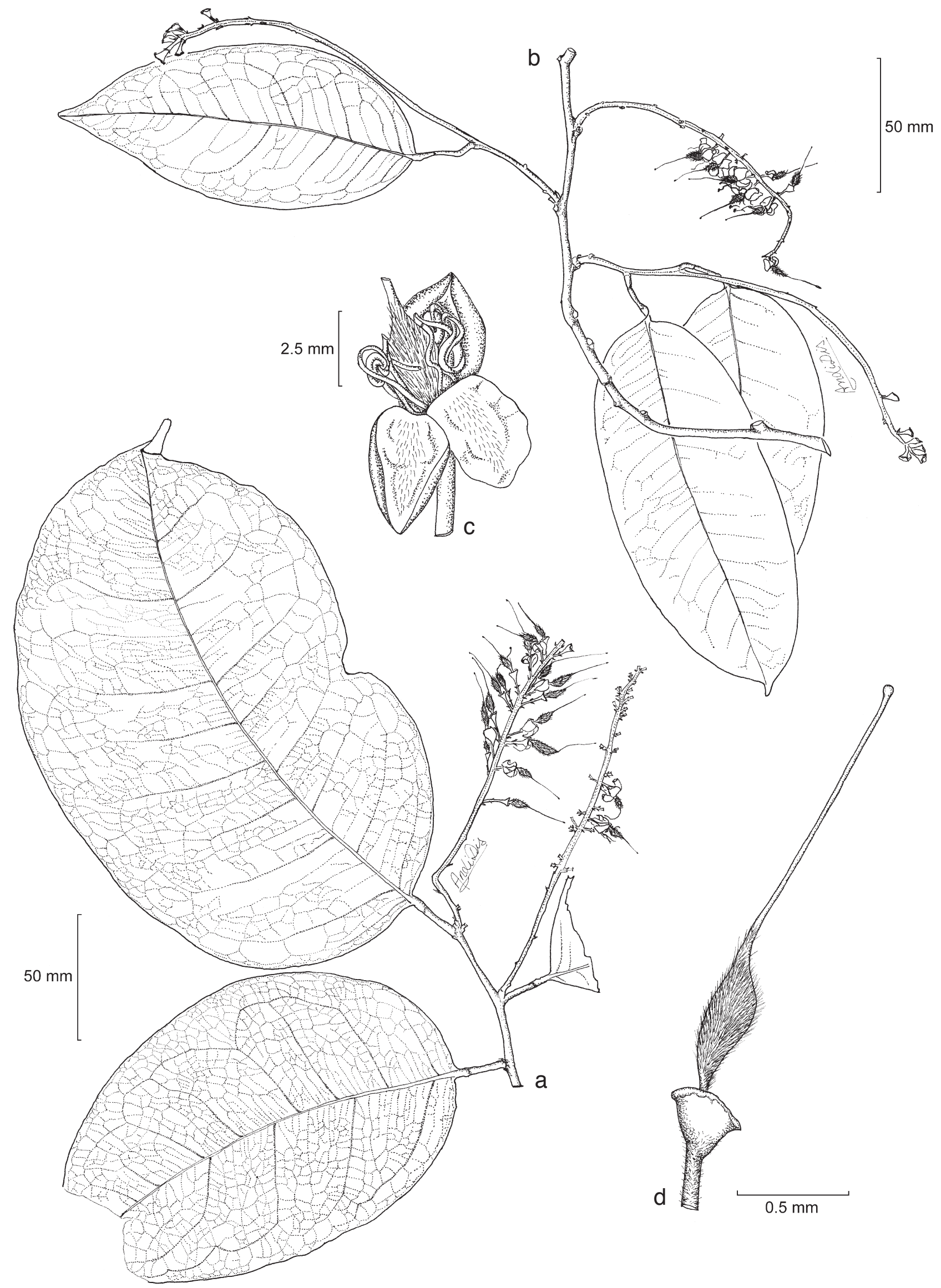

Fig. 1 Bocoa marionii Aymard \& H.E.Ireland. a, b. Branch with inflorescences; c. flower; d. post-anthesis gynoecium and calyx (a, c, d: Jansen-Jacobs et al. 5676 (PORT); b: Jansen-Jacobs 5734 (PORT)). 
pressed beneath. Inflorescence axillary racemes, borne among leaves, $10-15 \mathrm{~cm}$ long, 1-2 mm wide, rachis quadrangular, glabrous, bracteoles triangular-ovate, c. 2 by $0.5-1 \mathrm{~mm}$, glabrous, ciliolate at the apex; pedicels $4-8$ by c. $0.5 \mathrm{~mm}$, strigose pubescent. Flower bud ellipsoid; calyx c. $5 \mathrm{~mm}$ long, splitting near base into three segments, the segments equal, $3-4$ by c. $3 \mathrm{~mm}$, straight, oblong-elliptic, glabrous externally, medially strigose internally; petal absent; stamens 7-10, monomorphic, filaments $6-8$ by c. $0.2 \mathrm{~mm}$, glabrous, anthers c. 1.5 by c. 1.5 $\mathrm{mm}$, oblong; ovary $5-10$ by $3-5 \mathrm{~mm}$, densely yellow-sericeous pubescent, style $6-10 \mathrm{~mm}$ long, filiform, glabrous, stigma capitate, stipe $2-3$ by c. $0.2 \mathrm{~mm}$ wide, glabrous, fruit not seen.

Distribution - Guyana: Rewa River, Upper Essequibo region.

Habitat \& Ecology — In riparian forest, on loamy or sandy soils. At elevations of $160 \mathrm{~m}$.

Phenology - Flowers known from August and September.

Etymology - The epithet honors the collector of the type specimen, Marion Jansen-Jacobs, an authority on neotropical Verbenaceae, and editor of the Flora of the Guianas.

Note - Bocoa marionii is known from only two collections, and therefore, little is known about its full distribution and morphological variation. Bocoa marionii is most similar to $B$. prouacensis. The two species are unique among species of Bocoa in having unifoliolate leaves and 7-10 stamens. However, B. marionii differs from $B$. prouacensis principally in its chartaceous leaflets (vs coriaceous), shorter, axillary inflorescences borne among the leaves (vs larger, ramiflorous inflorescences), pedicels $4-8 \mathrm{~cm}$ long, strigose (vs $0.5-2 \mathrm{~cm}$ long, glabrous), calyx segments strigose internally (vs glabrous), and densely yellow-sericeous ovary (vs glabrous). The close relationship between $B$. marionii and $B$. prouacensis is significant because $B$. prouacensis is the type species of Bocoa, and if the genus is found to be non-monophyletic, $B$. marionii will probably stay in Bocoa.

Paratype. M. Jansen-Jacobs, B.J.H. ter Welle, P.P. Haripersaud, O. Muller \& M. van der Zee 5734 (PORT, U), Guyana, Upper Essequibo region, Rewa River, Corona falls, 03 $10^{\prime}$ N, 58 40' W, 160 m, 2 September 1999.

\section{KEY TO THE SPECIES OF BOCOA}

(Based on Ireland 2007)

1. Leaves unifoliolate; stamens $7-10 \ldots \ldots \ldots \ldots \ldots 2$

1. Leaves pinnate, rarely with an occasional unifoliolate leaf; stamens $25-65 \ldots \ldots \ldots \ldots \ldots$. . . . . . . . . . 3

2. Inflorescences axillary racemes; pedicels $4-8 \mathrm{~mm}$ long, strigose; ovary densely yellow-sericeous. - Guyana . . . . .......................... B. marionii

2. Inflorescences ramiflorous, pedicels $0.5-2 \mathrm{~mm}$ long, glabrous; ovary glabrous. - French Guiana, Suriname ... . . . . . . . . . . . . . . . . . . . . prouacensis

3. Leaves 3-foliolate (occasionally unifoliolate), the leafles opposite, glabrous above and beneath; stamens 25-30; tree 15-30 m tall. - Brazil: Pará and Amazonas, French Guiana, Suriname ... . . . . . . . . . . . B. viridiflora

3. Leaves 5- or 6-foliolate, leaflets alternate, white sericeous above, densely sericeous beneath in immature leaves (mature leaves not known); stamens 50-65; small tree about $2.5 \mathrm{~m}$ tall. - Brazil: Maranhão . . . . . . . . . B. ratteri
Acknowledgements We are grateful to A. Licata (PORT) for preparing the illustration, B. Manara (VEN) for revising the Latin description, to Paul Maas $(U)$ and the staff at the National Herbarium of the Netherlands, Utrech University branch, for making their facilities available for our research, and two anonymous reviewers for helpful comments on the manuscript.

\section{REFERENCES}

Cowan RS. 1974. A revision of the genus Bocoa (Caesalpinioideae-Swartzieae). Proceedings of the Biological Society of Washington 87: 95-128.

Cowan RS, Lindeman JC. 1989. Caesalpiniaceae. In: Görts-van Rijn ARA (ed), Flora of the Guianas, Ser. A 7: 1-167. Koeltz Scientific Books, Koenigstein

Ferguson IK, Schrire BD. 1994. A cladistic analysis of the pollen morphology of the tribe Swartzieae (Leguminosae). Acta Botanica Gallica 141: 207215.

Gasson P. 1996. Wood anatomy of the tribe Swartzieae with comments on related papilionoid and caesalpinoid Leguminosae. International Association of Wood Anatomists. News Bulletin 17: 45-75

Herendeen PS. 1995. Phylogenetic relationships of the Swartzieae. In: Crisp MD, Doyle JJ (eds), Advances in legume systematics 7: 123-132. Royal Botanic Gardens, Kew.

Ireland HE. 2005. Tribe Swartzieae. In: Lewis G, Schrire B, Mackinder B, Lock $M$ (eds), Legumes of the world. Royal Botanical Gardens, Kew Ireland HE. 2007. Taxonomic changes in the South American genus Bocoa (Leguminosae-Swartzieae): reinstatement of the name Trischidium, and a synopsis of both genera. Kew Bulletin 62: 333-349.

Ireland HE, Pennington RT, Preston J. 2000. Molecular systematics of the Swartzieae. In: Herendeen PS, Bruneau A (eds), Advances in legume systematics, part 9: 217-231. Royal Botanic Gardens, Kew

Kite GC, Ireland HE. 2002. Non-protein amino acids of Bocoa (Leguminosae; Papilionoideae). Phytochemistry 59: 163-168. 